\title{
Green coffee extract as a natural antioxidant in chill stored Indian mackerel (Rastrelliger kanagurta) mince
}

\author{
U. PARVATHY, G. K. SIVARAMAN*, L. N. MURTHY, S. VISNUVINAYAGAM, A. JEYAKUMARI \\ AND C. N. RAVISHANKAR* \\ Mumbai Research Centre of ICAR-Central Institute of Fisheries Technology, Vashi, Navi Mumbai - 400703 \\ Maharashtra, India \\ "ICAR-Central Institute of Fisheries Technology, Matsyapuri, Kochi - 682 029, Kerala, India \\ e-mail:p.pillai2012@gmail.com
}

\begin{abstract}
This study was carried out to evaluate the effect of green coffee extract as a natural antioxidant for retarding lipid oxidation and protein degradation in mackerel mince. Based on preliminary product acceptability study, mackerel mince with two different concentrations of the extract (1.0 and 1.5\%) and a control with no added extracts were prepared. Butylated hydroxytoluene, BHT $(200 \mathrm{ppm})$ was used for reference. The experimental lots were stored at $4^{\circ} \mathrm{C}$ and samples were collected at regular intervals for a period of 8 days and analysed for nutritional quality indices. Green coffee extract was found to be effective in retarding lipid oxidation, as indicated by low levels of thiobarbituric acid-reactive substance (TBARS), peroxide values and subsequent protein changes by salt soluble nitrogen (SSN) degradation and loss of sulphydryl group. A shelf life extension of two days was observed in green coffee extract incorporated mince, compared to control and BHT treated lots. Study suggested a concentration of $1 \%$ green coffee extract to be effective as natural antioxidant in oxidation sensitive systems like mackerel mince.
\end{abstract}

Keywords: Antioxidant, Green coffee, Lipid oxidation, Mince, Rastrelliger kanagurta

\section{Introduction}

The nutritional relevance of fish is well documented and fatty fishes in particular are of high dietary importance on account of their richness in essential omega-3 polyunsaturated fatty acids such as eicosapentaenoic acid (EPA) and docosahexaenoic acid (DHA). Inclusion of these fatty acids in diet can have potential human health benefits by prevention of many chronic lifestyle diseases (Lee and Lip, 2003). Though loaded with these benefits, a major constraint associated with the utilisation of fatty fish is their high sensitivity to oxidation resulting in numerous quality problems like undesirable odour, taste and colour in product (Frankel, 2005) as well as the health risk associated with the consumption of rancid fish. The most common method adopted for overcoming this problem is the use of antioxidant which can retard or reduce such quality changes. Natural antioxidants are getting wider publicity and consumer acceptance than the synthetic counterparts due to the toxicity and health risks associated with the latter (Anbudhasan et al., 2014). Hence in recent times natural phenolic compounds of plant origin such as green coffee extract, tea catechin and rosemary extract have been gaining increasing attention due to their safety as well as beneficial, functional and nutritional effects including antioxidant and antimicrobial activity (Frankel, 2005; Bubonja-Sonje et al., 2011). Studies have indicated these compounds as promising candidates for the protection of lipids against oxidation and associated deleterious effects to the tissues.

The annular molecular structure, conjugated double bonds and the presence of functional groups in the ring is accountable for the antioxidant activity of phenolic compounds (Dzialo et al., 2016) and they exhibit antioxidant property through different mechanisms of action such as free radical scavenging, metal chelation, inhibition and trapping of reactive oxygen species (ROS) (Liaudanskas et al., 2014; Alov et al., 2015). Chlorogenic acids (CGA) are phenolic compounds formed by the esterification of cinnamic acids and recent studies have reported a series of health benefits associated with the consumption of CGA. Green (or raw) coffee is a major natural source of CGA which in turn is associated with the in vitro and in vivo antioxidant capacity of green coffee (Shahidi and Chandrasekara, 2010).

Though there are a few studies on the in vitro antioxidant ability of green coffee, to the best of the authors' knowledge, there are no previous studies available regarding its application and effect in seafood systems. 
Fish mince is a highly convenient product as it cuts down the processing procedure and forms a base material for various comminuted products. But unlike whole fish, the shelf life of fish mince is shorter unless antioxidants and/or good packaging are used (Abdel-Aal, 2001). The objective of this study was therefore to comprehend more information regarding the potential of green coffee extract as an effective antioxidant source in fatty mince models like mackerel.

\section{Materials and methods}

\section{Fish, green coffee extract and chemicals}

Fresh Indian mackerel (Rastrelliger kanagurta) was purchased from local seafood market at Vashi, Mumbai and brought to the laboratory layered with ice in an insulated box and used immediately for the preparation of mince. Green coffee extract having a chlorogenic acid content of $65 \%$, was purchased from Perennial Life Sciences Pvt. Ltd, New Delhi. All chemicals used for the study were of analytical grade.

In vitro antioxidative properties

Total phenolic content (TPC) and DPPH (2, 2-Diphenyl1-picryhydrazyl) radical-scavenging activity

The method described by Singleton and Rossi (1965) was adopted with modifications for the determination of TPC. About $0.5 \mathrm{ml}$ of the extract $\left(1 \mathrm{mg} \mathrm{ml}^{-1}\right)$ was mixed with $2.5 \mathrm{ml}$ of ten times diluted Folin-Ciocalteu's reagent and allowed to react for $5 \mathrm{~min}$. To this, $2.5 \mathrm{ml}$ of $7.5 \%$ (w/v) sodium carbonate solution was added, kept at ambient temperature for $30 \mathrm{~min}$ and the absorbance was measured at $765 \mathrm{~nm}$ using a spectrophotometer (Lambda 25 UV/Vis, Perkin Elmer Life and Analytical Sciences, Singapore). The concentration of polyphenols in the extract was derived from gallic acid standard curve.

DPPH radical scavenging activity was measured using the method described by Shimada et al. (1992) with slight modifications. Green coffee extract was dissolved in distilled water to obtain different concentrations $\left(0.5-100 \mu \mathrm{g} \mathrm{ml}^{-1}\right)$. To $2 \mathrm{ml}$ of extract solutions, $2 \mathrm{ml}$ of $0.1 \mathrm{~mm}$ DPPH was added, mixed vigorously and incubated for $30 \mathrm{~min}$. Absorbance (Abs) of the resulting solution was measured at $517 \mathrm{~nm}$. Two $\mathrm{ml}$ of sample and $2 \mathrm{ml}$ of ethanol was used as sample blank and DPPH and distilled water was used as control. The scavenging activity was calculated as:

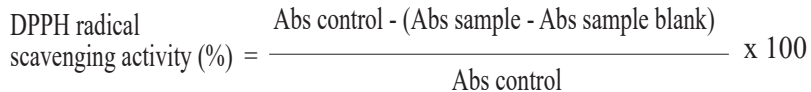

DPPH radical scavenging activity of $200 \mathrm{ppm}$ green coffee extract was also estimated along with butylated hydroxyanisole (BHA) and butylated hydroxytoluene (BHT) as positive controls. The antioxidant activity of the extract was expressed as $\mathrm{IC}_{50}$ (extract concentration required to scavenge $50 \%$ of DPPH radicals).

Reducing power and ferric reducing antioxidant power (FRAP)

The sample solution $(0.5 \mathrm{ml}, 200 \mathrm{ppm})$ was mixed with $2.5 \mathrm{ml}$ of $0.2 \mathrm{M}$ phosphate buffer $(\mathrm{pH} \mathrm{6.6)}$ and $2.5 \mathrm{ml}$ of $1 \%$ potassium ferricyanide and further incubated at $50^{\circ} \mathrm{C}$ for $20 \mathrm{~min}$. An aliquot $(2.5 \mathrm{ml})$ of $10 \%$ trichoroacetic acid was added to the mixture and centrifuged (K-24A, Remi Instruments, Mumbai) at $3000 \mathrm{rpm}$ for $10 \mathrm{~min}$. The upper layer of solution $(2.5 \mathrm{ml})$ was mixed with $2.5 \mathrm{ml}$ of distilled water and $2.5 \mathrm{ml}$ of $0.1 \%$ ferric chloride and the absorbance was read at $700 \mathrm{~nm}$ (Oyaiza, 1986). Increased absorbance of the reaction mixture indicated higher reducing power. BHA and BHT at $200 \mathrm{ppm}$ were used as positive control.

FRAP was assayed according to Benzie and Strain (1996). A working solution was prepared freshly by mixing stock solutions viz., $25 \mathrm{ml}$ of $300 \mathrm{~mm}$ acetate buffer (pH 3.6), $2.5 \mathrm{ml}$ of $10 \mathrm{~mm}$ TPTZ (2,4,6-tripyridyls-triazine) solution in $40 \mathrm{mM} \mathrm{HCl}$ and $2.5 \mathrm{ml}$ of $20 \mathrm{mM}$ $\mathrm{FeCl}_{3} \cdot 6 \mathrm{H}_{2} \mathrm{O}$ solution. The mixed solution was incubated at $37^{\circ} \mathrm{C}$ for $30 \mathrm{~min}$ and was referred to as FRAP solution. One hundred and fifty microlitre of sample ( 0.2 and $1.0 \mathrm{mg} \mathrm{ml}^{-1}$ ) was mixed with $2850 \mu \mathrm{l}$ of FRAP solution and kept for $30 \mathrm{~min}$ in dark. The ferrous tripyridyltriazine complex (coloured product) was measured by reading the absorbance at $593 \mathrm{~nm}$. Ascorbic acid standard curve for FRAP was derived and the activity was expressed as $\mu \mathrm{M}$ Ascorbic acid equivalents. BHA and BHT at 200 ppm were used for comparison.

\section{Antimicrobial property}

Antimicrobial property was determined as per CLSI (2012) standard well diffusion technique using Muller Hinton Agar (MHA). Test bacterial culture were inoculated into Brain Heart Infusion Broth (BHI) and incubated at $37^{\circ} \mathrm{C}$ for $2-4 \mathrm{~h}$. The grown cultures were adjusted with sterile normal saline solution until $0.5 \mathrm{Mc}$ Farland standard turbidity appeared. Sterile cotton swab was immersed into test culture and spread over preset MHA plates. Wells of 5-6 $\mathrm{mm}$ dia were formed on the plates using cork borer and the bottom of the wells were sealed with sterile molten agar to avoid leakage. The prepared samples of known concentrations were added into the wells and the plates were incubated at $37^{\circ} \mathrm{C}$. After $24 \mathrm{~h}$, inhibition zone was measured using standard antibiotic zone scale. Minimum Inhibitory Concentration (MIC) of 
the extract was analysed using sterile 96 well micro titre plates as per EUCAST (2003). One hundred microlitre of green coffee extract $\left(0.5 \mathrm{~g} \mathrm{ml}^{-1}\right)$ was added in the first well containing $100 \mu \mathrm{l}$ of Muller Hinton Broth (MHB) followed by thorough mixing. This was followed by serial dilutions ( 2 fold dilution) up to last well (11 $1^{\text {th }}$ well). Finally, $10 \mu \mathrm{l}$ containing test culture (3-7 x 10 4 CFU) was added into all wells in the row with a final concentration reaching $5 \times 10^{5} \mathrm{CFU} \mathrm{ml}^{-1}$. After incubation for 10-16 h, the highest dilution showing no visible growth in 96 well plates was considered as MIC. Similarly, highest dilution showing no bacterial growth confirmed by plating was considered as Minimum Bactericidal Concentration (MBC).

\section{Product acceptability study}

A preliminary product acceptability study was carried out to finalise the concentration of green coffee extract incorporation in mince and mince based products. For this, fish cake was prepared from the mince of Indian mackerel following the methodology of Suzuki (1981). Extract was incorporated @ 0.5-1.5\% levels and sensory evaluation was carried out with ten trained panellists for different attributes like appearance, odour, flavour, colour and texture on a continuous intensity scale ranging from 1 to a maximum intensity of 9 as prescribed by Meilgaard et al. (2006).

\section{Storage study of mackerel mince}

Fresh Indian mackerel meat was manually picked free of bones and skin and minced using a kitchen blender after addition of antioxidants viz., green coffee extract at $1.0 \%$ and $1.5 \%$ as well as BHT (200 ppm) in different lots. Mince without addition of any antioxidant was made in a similar manner and was used as control. The samples were coded as $\mathrm{MGC}_{1.0}, \mathrm{MGC}_{1.5}, \mathrm{MBHT}$ and $\mathrm{MC}$, respectively. Additives viz., green coffee extract and $\mathrm{BHT}$ were dissolved in known and limited volume of distilled water and added to the mince for even distribution of the antioxidant in the mince. In the control sample, same quantity of distilled water without additive was added for uniformity in treatment. Each lot was evenly packed as rectangular slabs in polythene bags and stored under chilled condition $\left(4^{\circ} \mathrm{C}\right)$ and sampling was done at regular intervals for a period of 8 days.

\section{Proximate composition, $\mathrm{pH}$ and colour}

Evaluation of mackerel mince for its nutritional aspects in terms of proximate composition was carried out as per AOAC (2012). Total nitrogen and crude protein contents were estimated by Micro Kjeldahl method. About $5 \mathrm{~g}$ mince sample was blended with $45 \mathrm{ml}$ distilled water and $\mathrm{pH}$ of the homogenate was measured using pH meter (ECPH S1042S, Eutech Instruments, Singapore).
The colour of mince was evaluated using Hunter Lab colorimeter (Colorflex EZ 45/0, Hunter Associates Lab Inc., Reston, Virginia, USA) to produce numeric results indicative of the colour of the sample by measuring $\mathrm{L}^{*}$ (lightness), $\mathrm{a}^{*}$ [redness $(+) /$ greenness $\left.(-)\right]$ and $\mathrm{b}^{*}$ [yellowness $(+) /$ blueness $(-)$ ] values.

Peroxide value $(P V)$ and thiobarbituric acid-reactive substance (TBARS)

Oxidative rancidity indices viz., PV and TBARS were estimated for the mince samples during chill storage. PV was determined iodimetrically after proper sample dehydration followed by fat extraction using chloroform (AOAC, 1989). TBARS was measured (Tarladgis et al., 1960) spectrophotometrically at $532 \mathrm{~nm}$ and expressed as mg malonaldehyde per $\mathrm{kg}$ sample.

\section{Expressible moisture}

Expressible moisture content was measured according to the method of Suzuki (1981) with slight modifications. About one gram of sample was weighed and placed between two filter papers and a pressure of $5 \mathrm{~kg} \mathrm{~cm}^{-2}$ was applied for a period of $60 \mathrm{sec}$. The weight of the pressed sample was again noted. The difference in weight was expressed as percentage of weight of the initial sample.

\section{Salt soluble nitrogen (SSN)}

SSN was determined following the method of AOAC (2012) with modifications. A known quantity of sample was weighed accurately and homogenised with chilled extraction buffer $(1 \mathrm{M} \mathrm{NaCl}$ in $0.05 \mathrm{M}$ phosphate buffer, $\mathrm{pH}$ 7.0) in the ratio 1:10 (sample:buffer). It was then homogenised (230 VAC T-25 digital Ultra-turrax, IKA, India) in chilled condition for 2-3 min and kept for $30 \mathrm{~min}$. Further, the sample was centrifuged (K-24A, Remi Instruments, Mumbai) at $7000 \mathrm{rpm}$ for $15 \mathrm{~min}$. Supernatant thus obtained was collected and protein estimated as per Lowry et al. (1951).

\section{Sulphydryl group}

Ellman's method (1959) with slight modifications was adopted for the determination of sulphydryl group. Sample $(0.5 \mathrm{~g})$ was homogenised in $10 \mathrm{ml}$ of $0.05 \mathrm{M}$ phosphate buffer $(\mathrm{pH} \mathrm{7.2)}$ for $30 \mathrm{~s}$. One $\mathrm{ml}$ of the homogenate was mixed with $9 \mathrm{ml}$ of $0.05 \mathrm{~m}$ phosphate buffer $(\mathrm{pH} 7.2$ containing $0.6 \mathrm{M} \mathrm{NaCl}, 6 \mathrm{~mm}$ EDTA and $8 \mathrm{M}$ urea) and the mixture was centrifuged at $10,000 \mathrm{rpm}$ for $10 \mathrm{~min}$ at $5^{\circ} \mathrm{C}$. To $3 \mathrm{ml}$ of the supernatant, $0.04 \mathrm{ml}$ of $0.01 \mathrm{M} \mathrm{DTNB}$ 5,5-dithio-bis-(2-nitrobenzoic acid) solution in $0.05 \mathrm{M}$ sodium acetate were added and incubated at $40^{\circ} \mathrm{C}$ for 15 min. A blank was prepared replacing the homogenate with $0.05 \mathrm{M}$ phosphate buffer $(\mathrm{pH} 7.2$ containing 
0.6 $\mathrm{M} \mathrm{NaCl}, 6 \mathrm{~mm}$ EDTA and $8 \mathrm{M}$ urea). The absorbance was measured at $412 \mathrm{nM}$ and the sulphydryl content was calculated using a molar extinction coefficient of $13,600 \mathrm{M}^{-1} \mathrm{~cm}^{-1}$.

\section{Sensory evaluation}

Sensory analysis of mince during storage was performed by a group of 10 trained panellists using a 9-point hedonic scale for attributes viz., appearance, colour, texture, aroma and taste using score sheets as prescribed by Meilgaard et al. (2006) for both raw and cooked samples (cooked in 1.5\% brine for $10 \mathrm{~min}$ ). The overall acceptability was evaluated on the basis of these attributes. Final judgments were made based on the average scores given by all panellists.

\section{Microbiological analysis}

Aerobic plate count was enumerated following the methodology prescribed by USFDA (2001) adopting serial dilution of blended sample using pour plate technique.

\section{Statistical analysis}

The data obtained for all the analysis (in triplicate) were subjected to analysis of variance (ANOVA) and the differences between means were evaluated by Duncan's multiple range test. SPSS statistical software (SPSS 16.0 for Windows, SPSS Inc., Chicago, IL) was used for interpretation of the results.

\section{Results and discussion}

In vitro antioxidative properties

Total phenolic content (TPC) and DPPH radicalscavenging activity

The ability of phenolic substances including flavonoids and phenolic acid to act as antioxidants has been extensively investigated (Fecka et al., 2007; Shahidi, 2008). Green coffee, a rich and natural source of phenolic compounds especially chlorogenic acid was found to have a total phenolic content of $203.26 \pm 1.98 \mathrm{~g} \mathrm{~kg}^{-1}$ extract. Elliot (1999) reported the existence of a positive relationship between antioxidant activity and phenolic contents in crude extracts.

DPPH assay is widely used to study the ability of compounds to act as free radical scavengers or hydrogen donors and to evaluate antioxidant capacity of foods (Pyrzynska and Pekal, 2013). DPPH radical scavenging activity of green coffee extract (200 ppm) was $86.08 \pm 1.3 \%$ in comparison to that for the same concentration of commonly used synthetic antioxidants viz., BHA (92.58 $\pm 1.54 \%)$ and BHT (37.24 $\pm 0.21 \%)$. Results indicated the potential antioxidant activity of green coffee extract with high DPPH radical scavenging value comparable to the synthetic ones. $\mathrm{IC}_{50}$ of the extract was $32.66 \mu \mathrm{g} \mathrm{ml}^{-1}$. Fidrianny et al. (2016) reported DPPH radical scavenging activities of various extracts of Arabica green coffee from different regions with an $\mathrm{IC}_{50}$ ranging between 0.70 to $134.56 \mu \mathrm{g} \mathrm{ml}^{-1}$. According to Blois (1958), samples having $\mathrm{IC}_{50}$ lower than $50 \mu \mathrm{g} \mathrm{ml}^{-1}$ are regarded as very strong antioxidants and hence the green coffee extract used for the present study can be categorised as a very strong antioxidant.

\section{Reducing power and FRAP}

The antioxidant activity is assumed to be related to the degree of reducing capacity of a sample which is mainly contributed by the hydroxyl groups linked with a benzene ring in an antioxidant molecule (Sentkowska et al., 2016). The reducing power of green coffee extract (200 ppm) was observed to be $0.109 \pm 0.008$ whereas those of BHA and BHT (200 ppm each) were $0.510 \pm 0.001$ and $0.267 \pm 0.002$, respectively. The FRAP of green coffee extract was $245.06 \pm 7.98 \mu \mathrm{M}$ AAE $(200 \mathrm{ppm})$ and $1111.36 \pm 15.21 \mu \mathrm{M}$ AAE (1000 ppm), respectively in comparison to FRAP of $200 \mathrm{ppm}$ of BHA (1001.3 $\pm 8.12 \mu \mathrm{M}$ AAE) and BHT (566.3 $\pm 26.19 \mu \mathrm{M}$ AAE). Siva et al. (2016) reported an FRAP of green coffee (Robusta sp.) varying from 0.15 and $0.48 \mathrm{mg} \mathrm{g}^{-1}$ depending on the effectiveness of extraction solvent used. Synthetic antioxidants have approval for use in food at low concentrations on the basis of complex toxicity studies and have been proved to share a number of toxic properties at high concentrations (Shahidi, 2005). The recommended levels of synthetic antioxidants like BHA/BHT in food are $200 \mathrm{ppm}$ whereas on account of safety, higher levels of natural antioxidants are used in food systems. Hence in the present study, the lower reducing property exhibited by green coffee extract in comparison to same levels of BHA/BHT can be met by higher levels of extract incorporation in food systems.

\section{Antimicrobial property}

Microorganisms are one of the major causes of spoilage in seafood. Gram and Dalgaard (2002) mentioned that only a few members of microbial community are responsible for majority of food spoilage, termed as specific spoilage organisms (SSOs). Control of these SSOs is much important to increase the shelf life of seafood and recently various natural components have been attempted by researchers to control SSOs for improved storage stability of seafoods. Studies on the antimicrobial activity of green coffee extract against major food borne pathogenic and fish spoilage bacteria viz., Salmonella, Escherichia coli, Vibrio cholerae, Staphylococcus aureus, Listeria monocytogenes, Bacillus cereus, Brochothrix thermosphacta, Pseudomonas sp., Lactobacillus sp. and $\mathrm{H}_{2} \mathrm{~S}$ forming bacteria were carried out. S. aureus, 
B. thermosphacta and B. cereus were found to be relatively highly susceptible to green coffee extract with a zone of inhibition of $20 \mathrm{~mm}$ (S. aureus), $21 \mathrm{~mm}$ (B. thermosphacta) and $19 \mathrm{~mm}$ (B. cereus) respectively for $0.5 \mathrm{~g} \mathrm{ml}^{-1}$ extract concentration. However, other bacterial population were found to be resistant to green coffee extract at the tested concentration of $0.5 \mathrm{~g} \mathrm{ml}^{-1}$. S. aureus, B. thermosphacta and $B$. cereus were inhibited when a concentration of 125 , 31.25 and $62.5 \mathrm{mg} \mathrm{ml}^{-1}$ respectively of green coffee extract were used and the bactericidal concentrations were 250, 62.5 and $125 \mathrm{mg} \mathrm{ml}^{-1}$ respectively. In the present study, it was also observed that all the susceptible organisms viz., S. aureus, B. thermosphacta and B. cereus were Gram positive. Fardiaz (1995), in his study reported different bacteria to have different sensitivity to antimicrobial compounds. He also observed that the non-volatile organic acids found in coffee inhibited the growth of some Gram positive and Gram negative bacteria. As observed in the present study, Gram positive bacteria viz., S. aureus, $B$. cereus and L. bulgaricus were more susceptible in plate count agar with higher chances of inhibition at lower concentrations of coffee extract in comparison to Gram negative ones. Bharath et al. (2015) have proved antibacterial activity of green coffee bean extract against periodonto pathogenic bacteria with a low MIC and MBC values both ranging between $0.2 \mu \mathrm{g} \mathrm{ml}^{-1}$ to $3.125 \mathrm{~g} \mathrm{ml}^{-1}$.

\section{Product acceptability study}

Market acceptance of a product is the most important parameter for its successful launching and product acceptability study is the measure by which it is seen whether the product is able to satisfy a large customer base so as to continue or increase its current production (Garces et al., 2016). Product acceptability study was carried out initially to finalise the concentration of green coffee extract incorporation in mince based product viz., fish cake. Even the highest concentration of green coffee incorporation in the product $(1.5 \%)$ did not show any flavour detection or rejection and hence was selected for further storage studies together with $1 \%$ concentration for comparison purpose.

\section{Storage study of mackerel mince}

\section{Proximate composition, $\mathrm{pH}$ and colour}

Knowledge on the chemical composition of food is important for effective dietary utilisation as well as for elaborating its role in functional food development. Proximate analysis of mackerel mince indicated $74.73 \pm 0.38 \%$ moisture content; $20.51 \pm 0.31 \%$ protein; $1.74 \pm 0.03 \%$ fat and $1.35 \pm 0.002 \%$ ash. Nisa and Asadullah (2011) reported that chemical composition of the Indian mackerel ( $R$. kanagurta) from Karachi coast varied seasonally from $70.11-74.41 \%, 16.02-20.09 \%, 3.0-12 \%$ and $0.89-1.35 \%$ for moisture, crude protein, fat and ash contents, respectively.

Initial $\mathrm{pH}$ of the mince was 6.46 whereas in green coffee extract incorporated samples $\left(\mathrm{MGC}_{1.0}\right.$ and $\left.\mathrm{MGC}_{1.5}\right)$, a comparatively lower $\mathrm{pH}$ was observed which might be due to the chlorogenic acid content present in the extract. $\mathrm{pH}$ of the chill stored mince lots increased significantly $(p<0.05)$ in green coffee extract treated ones during storage, whereas the increase was not significant in control (MC) and MBHT. Similarly, significant variations were observed between the green coffee extract treated ones; MC and MBHT lots (Table 1). Viji et al. (2015) also observed a marginal increase in the $\mathrm{pH}$ of untreated and plant extract (mint leaf and citrus peel) treated mackerel fish during chill storage. Chaijana et al. (2005) reported a gradual increase in the $\mathrm{pH}$ of mackerel (R. kanagurta) muscle during 15 days of ice storage which was postulated to be due to an increase in volatile bases produced by either endogenous or microbial enzymes.

Colour of fish mince is affected by different constituents in fish viz., red or brown pigment from blood and dark muscles. These pigments are especially vulnerable to oxidation causing deep yellow or brown discoloration during handling, chilling and frozen storage (Pearson and Dutson, 1994). Analysis of colour of the samples indicated that all the lots became significantly darker $(\mathrm{p}<0.05)$ during storage as indicated by decreased $\mathrm{L}^{*}$ values (Table 2 ). $\mathrm{L}^{*}$ values varied significantly between the samples $(\mathrm{p}<0.05)$ with $\mathrm{MGC}_{1.0}$ and $\mathrm{MGC}_{1.5}$ being comparatively more darker than the other lots which must be on account of the darker colour of the added green coffee extract. Similarly, redness values $\left(\mathrm{a}^{*}\right)$ varied significantly $(p<0.05)$ between the samples with more redness for green coffee extract treated samples compared to others. Redness increased in all the sample lots during storage as indicated by increasing $\mathrm{a}^{*}$ values whereas a significant reduction in yellowness $(\mathrm{p}<0.05)$ during storage was observed (Table 2). Although the colour changes are mainly associated with lipid or protein oxidation, the colour changes in the present investigation was difficult to interpret, as the green coffee extracts itself contributed some colour (greenish brown) in the incorporated mince lots. Farvin et al. (2012) stated similar problems associated with potato peel extract incorporation in chill stored horse mackerel mince.

Peroxide value $(P V)$ and thiobarbituric acid-reactive substance (TBARS)

Lipid oxidation, the major quality problem associated with fatty fishes ultimately leads to associated undesirable changes affecting its taste, smell, texture, colour and nutritional value. Keeping track of these oxidative 
Table 1. Variations in physicochemical, sensory and microbiological parameters of mackerel mince during chill storage at $4^{\circ} \mathrm{C}$

\begin{tabular}{llllll}
\hline Parameters & Storage days & MC & MGC $_{1.0}$ & MGC $_{1.5}$ & MBHT \\
\hline $\mathrm{pH}$ & 0 & $6.46 \pm 0.01^{\mathrm{aA}}$ & $6.46 \pm 0.01^{\mathrm{aD}}$ & $6.46 \pm 0.01^{\mathrm{aD}}$ & $6.46 \pm 0.01^{\mathrm{aA}}$ \\
& 2 & $6.47 \pm 0.03^{\mathrm{cA}}$ & $6.26 \pm 0.02^{\mathrm{bA}}$ & $6.17 \pm 0.03^{\mathrm{aA}}$ & $6.46 \pm 0.02^{\mathrm{cA}}$ \\
& 4 & $6.49 \pm 0.01^{\mathrm{cA}}$ & $6.37 \pm 0.03^{\mathrm{bB}}$ & $6.25 \pm 0.01^{\mathrm{aB}}$ & $6.52 \pm 0.01^{\mathrm{cA}}$ \\
& 6 & $6.59 \pm 0.02^{\mathrm{dB}}$ & $6.41 \pm 0.01^{\mathrm{bC}}$ & $6.33 \pm 0.02^{\mathrm{aC}}$ & $6.54 \pm 0.02^{\mathrm{cA}}$ \\
Expressible moisture & 8 & - & $6.47 \pm 0.02^{\mathrm{aD}}$ & $6.47 \pm 0.01^{\mathrm{aD}}$ & - \\
& 0 & $22.6 \pm 0.77^{\mathrm{aA}}$ & $22.6 \pm 0.77^{\mathrm{aA}}$ & $22.6 \pm 0.77^{\mathrm{aA}}$ & $22.6 \pm 0.77^{\mathrm{aA}}$ \\
& 2 & $25.23 \pm 0.80^{\mathrm{bB}}$ & $22.63 \pm 0.27^{\mathrm{aA}}$ & $23.63 \pm 0.49^{\mathrm{aA}}$ & $26.49 \pm 0.50^{\mathrm{cB}}$ \\
& 4 & $26.16 \pm 0.17^{\mathrm{bB}}$ & $26.34 \pm 0.40^{\mathrm{bB}}$ & $24.91 \pm 0.98^{\mathrm{aB}}$ & $26.54 \pm 0.44^{\mathrm{bB}}$ \\
SSN & 6 & $28.15 \pm 0.34^{\mathrm{bC}}$ & $25.7 \pm 1.12^{\mathrm{aB}}$ & $29.71 \pm 0.56^{\mathrm{cC}}$ & $29.65 \pm 0.44^{\mathrm{cC}}$ \\
& 8 & $33.77 \pm 1.10^{\mathrm{aC}}$ & $33.13 \pm 0.65^{\mathrm{aD}}$ & - \\
& 0 & $27.93 \pm 0.06^{\mathrm{aC}}$ & $27.93 \pm 0.06^{\mathrm{aC}}$ & $27.93 \pm 0.06^{\mathrm{aC}}$ & $27.93 \pm 0.06^{\mathrm{aC}}$ \\
& 2 & $25.17 \pm 0.15^{\mathrm{abB}}$ & $26.10 \pm 0.61^{\mathrm{bcB}}$ & $26.60 \pm 0.26^{\mathrm{cC}}$ & $24.17 \pm 0.85^{\mathrm{aB}}$ \\
TPC & 4 & $26.00 \pm 1.42^{\mathrm{cB}}$ & $24.20 \pm 0.87^{\mathrm{bB}}$ & $23.80 \pm 0.36^{\mathrm{abB}}$ \\
& 6 & $22.63 \pm 0.76^{\mathrm{aA}}$ & $24.27 \pm 1.16^{\mathrm{bB}}$ & $21.80 \pm 1.05^{\mathrm{aA}}$ \\
& 8 & $21.80 \pm 1.01^{\mathrm{aA}}$ & $21.30 \pm 0.50^{\mathrm{aA}}$ & $21.10 \pm 0.61^{\mathrm{aA}}$ & - \\
& 0 & $3.72 \pm 0.01^{\mathrm{aA}}$ & $3.72 \pm 0.01^{\mathrm{aA}}$ & $3.72 \pm 0.01^{\mathrm{aA}}$ \\
& 2 & $5.31 \pm 0.01^{\mathrm{cB}}$ & $5.24 \pm 0.01^{\mathrm{bB}}$ & $5.19 \pm 0.01^{\mathrm{aB}}$ \\
& 4 & $6.24 \pm 0.03^{\mathrm{dC}}$ & $5.93 \pm 0.03^{\mathrm{aC}}$ & $6.11 \pm 0.02^{\mathrm{cC}}$ \\
& 6 & $6.27 \pm 0.01^{\mathrm{bcD}}$ & $6.21 \pm 0.01^{\mathrm{aD}}$ & $6.25 \pm 0.01^{\mathrm{bD}}$
\end{tabular}

Values are expressed as Mean $\pm \mathrm{SD} ; \mathrm{n}=3$ and $\mathrm{n}=10$ (sensory score); Means bearing different superscripts in same row (lower case) and in same column (upper case) are significantly different $(\mathrm{p}<0.05)$

Table 2. Variations in colour of mackerel mince during chill storage at $4^{\circ} \mathrm{C}$

\begin{tabular}{llllll}
\hline Colour parameters & Storage days & $\mathrm{MC}$ & $\mathrm{MGC}_{1.0}$ & $\mathrm{MGC}_{1.5}$ & $\mathrm{MBHT}$ \\
\hline $\mathrm{L}^{*}$ & 0 & $52.11 \pm 0.02^{\mathrm{aC}}$ & $52.11 \pm 0.02^{\mathrm{aE}}$ & $52.11 \pm 0.02^{\mathrm{aE}}$ & $52.11 \pm 0.02^{\mathrm{aD}}$ \\
& 2 & $50.41 \pm 0.06^{\mathrm{cB}}$ & $50.07 \pm 0.08^{\mathrm{bD}}$ & $50.55 \pm 0.07^{\mathrm{cD}}$ & $49.48 \pm 0.19^{\mathrm{aC}}$ \\
& 4 & $49.63 \pm 0.09^{\mathrm{dA}}$ & $46.97 \pm 0.04^{\mathrm{bC}}$ & $45.42 \pm 0.15^{\mathrm{aB}}$ & $47.66 \pm 0.14^{\mathrm{cB}}$ \\
& 6 & $46.00 \pm 0.13^{\mathrm{bA}}$ & $45.81 \pm 0.03^{\mathrm{aC}}$ & $47.44 \pm 0.02^{\mathrm{cA}}$ \\
$\mathrm{a}^{*}$ & 8 & $46.53 \pm 0.10^{\mathrm{dA}}$ & $3.04^{\mathrm{bB}}$ & $45.24 \pm 0.02^{\mathrm{aA}}$ & - \\
& 0 & $3.61 \pm 0.02^{\mathrm{aA}}$ & $3.61 \pm 0.02^{\mathrm{aA}}$ & $3.61 \pm 0.02^{\mathrm{aA}}$ & $3.61 \pm 0.02^{\mathrm{aA}}$ \\
& 2 & $3.74 \pm 0.01^{\mathrm{aA}}$ & $4.12 \pm 0.02^{\mathrm{bB}}$ & $4.03 \pm 0.01^{\mathrm{bB}}$ & $4.99 \pm 0.01^{\mathrm{cC}}$ \\
& 4 & $4.24 \pm 0.07^{\mathrm{aB}}$ & $4.86 \pm 0.07^{\mathrm{bC}}$ & $6.56 \pm 0.03^{\mathrm{cC}}$ & $4.82 \pm 0.09^{\mathrm{bB}}$ \\
$\mathrm{b}^{*}$ & $4.19 \pm 0.07^{\mathrm{aB}}$ & $6.69 \pm 0.15^{\mathrm{cE}}$ & $7.21 \pm 0.02^{\mathrm{dE}}$ & $5.87 \pm 0.16^{\mathrm{bD}}$ \\
& 6 & - & $6.28 \pm 0.14^{\mathrm{aD}}$ & $7.06 \pm 0.06^{\mathrm{bD}}$ & - \\
& 8 & $17.34 \pm 0.03^{\mathrm{aD}}$ & $17.34 \pm 0.03^{\mathrm{aD}}$ & $17.34 \pm 0.03^{\mathrm{aD}}$ & $17.34 \pm 0.03^{\mathrm{aD}}$ \\
& 0 & $16.53 \pm 0.02^{\mathrm{bB}}$ & $17.39 \pm 0.07^{\mathrm{cD}}$ & $17.53 \pm 0.04^{\mathrm{dE}}$ & $15.87 \pm 0.03^{\mathrm{aC}}$ \\
& 2 & $16.81 \pm 0.04^{\mathrm{bC}}$ & $16.99 \pm 0.16^{\mathrm{cC}}$ & $17.04 \pm 0.05^{\mathrm{cC}}$ & $15.35 \pm 0.02^{\mathrm{aA}}$ \\
& 4 & $16.16 \pm 0.05^{\mathrm{bA}}$ & $16.13 \pm 0.04^{\mathrm{bB}}$ & $16.46 \pm 0.10^{\mathrm{cB}}$ & $15.48 \pm 0.07^{\mathrm{aB}}$ \\
\hline
\end{tabular}

Values are expressed as Mean $\pm \mathrm{SD} ; \mathrm{n}=3$; Means bearing different superscripts in same row (lower case) and in same column (upper case) are significantly different $(\mathrm{p}<0.05)$

changes is usually met by indices viz., PV and TBARS. In the present study, PV indicated a significant increase $(p<0.05)$ in all lots during storage as well as the changes were significantly different $(\mathrm{p}<0.05)$ between the sample groups (Fig. 1). However, the initial variations in PV were not prominent between green coffee extract treated samples $\left(\mathrm{MGC}_{1.0}\right.$ and $\left.\mathrm{MGC}_{1.5}\right)$.

Similarly, variations in TBARS were significant $(\mathrm{p}<0.05)$ among the sample lots (Fig. 2). In MC and MBHT, a significant increase $(\mathrm{p}<0.05)$ in TBARS was 


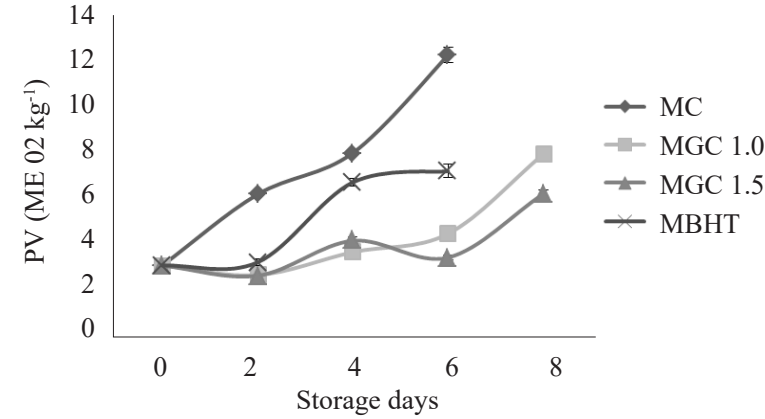

Fig. 1. Variations in peroxide value of Indian mackerel mince during chill storage at $4^{\circ} \mathrm{C}$

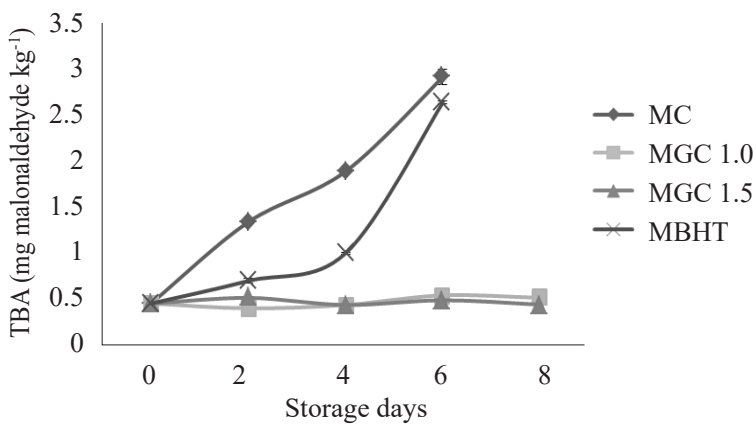

Fig. 2. Variations in TBARS of Indian mackerel mince during chill storage at $4^{\circ} \mathrm{C}$

observed whereas in green coffee extract treated samples TBARS values were comparatively lower and the rate of increase was not significant during chill storage. Both $\mathrm{MC}$ and MBHT reached the TBA acceptability limit of $2 \mathrm{mg}$ malonaldehyde $\mathrm{kg}^{-1}$ (Connell, 1990) on $6^{\text {th }}$ day and it was well related with the sensory changes wherein both samples developed an objectionable odour/taste. However this correlation between TBARS and sensory changes was not observed in green coffee treated samples whereas PV was found to be on an increasing mode in green coffee treated samples during storage. The above results indicated a higher lipid oxidation retardation in green coffee extract treated mackerel mince which correlates well with high total phenolic content as well as in vitro antioxidant properties of the extract. Medina et al. (2007) reported that the reducing capacity of phenolic antioxidants was the key responsible function for retarding and inhibiting lipid oxidation in fish tissues.

\section{Expressible moisture}

The water holding capacity of meat products is a very important quality attribute as it affects the eating quality as well as the product yield thus having economic implications (Cheng and Sun, 2008). Expressible moisture content is related to water holding capacity of samples and in the present study, expressible moisture content was found to increase in all lots but was not significant throughout the storage period (Table 1). Rawdkuen et al. (2009) stated that the changes in the nature of actin and myosin molecules during storage lead to reduced water holding capacity which increases the free water in matrix. Parvathy and George (2014) have reported that the higher expressible moisture can be a consequence of increased protein denaturation of samples leading to corresponding decrease in water holding capacity, the changes being more prominent during frozen storage.

\section{Salt soluble nitrogen (SSN)}

Myofibrillar protein, the salt soluble fraction in fish protein undergo denaturation during storage and the primary as well as secondary lipid oxidation products accelerate the process leading to the loss of protein functionality, thereby affecting the food muscle quality (Baron et al., 2007). Hence salt soluble nitrogen (SSN) content of fish meat can be used as an indicator of the extent of denaturation of myofibrillar proteins which is reflected by a significant decrease in solubility of the myofibrillar fraction and associated textural meat quality (Badii and Howell, 2002). Present study indicated a significant decrease in the rate of SSN during storage, especially during the initial storage period except for $\mathrm{MGC}_{1.5}$ (Table 1). Similar findings were reported by Suvanich et al. (2000) in catfish frame mince where myofibrillar protein reported a significant reduction during storage at $5^{\circ} \mathrm{C}$. The rate of loss in SSN was comparatively lower in green coffee extract treated samples indicating their protection against fat oxidation which in turn influenced the protein functionality.

\section{Sulphydryl group}

Sulphydryl group or thiol group is a functional group consisting of sulphur bonded to a hydrogen atom. Generally as storage progresses, a decrease in total sulphydryl group occurs on account of the formation of disulphide bonds through oxidation of sulphydryl groups or disulphide interchanges (Lanier, 2000). Disulphide bonding in turn results in protein aggregation, lowering the protein solubility and hence is related to changes in SSN. Green coffee extract treated samples indicated a significantly lower loss of sulphydryl groups $(p<0.05)$ compared to the other lots which might be due to better oxidation protection and the variations in samples were significant during storage period (Fig. 3). Farvin et al. (2012) reported a significant decrease in thiol group in all lots of chill stored horse mackerel mince except in mince containing higher levels $\left(4.8 \mathrm{~g} \mathrm{~kg}^{-1}\right)$ of potato peel ethanol extract. 


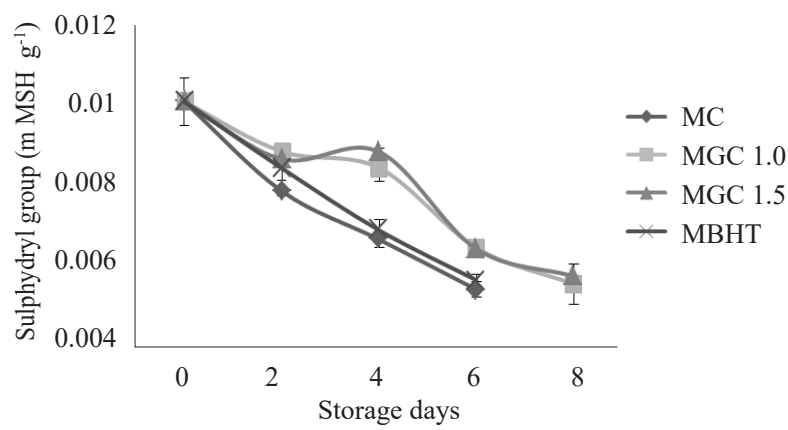

Fig. 3. Variations in sulphydryl group of Indian mackerel mince during chill storage at $4^{\circ} \mathrm{C}$

\section{Sensory evaluation}

Effectiveness in recognising the complexities marks sensory analysis as the ultimate quality evaluation technique for determining the shelf stability of a product. Generally, variations in biochemical indices correlate well with the sensory scores. An increased off-flavour and odour was observed for all the samples during storage indicated by significantly decreased sensory scores during the study (Table 1). The variations in sensory scores were also significant $(p<0.05)$ between the sample lots with better sensory acceptability for green coffee extract treated samples. MC and MBHT reached the sensory acceptability limit on $6^{\text {th }}$ day whereas $\mathrm{MGC}_{1.0}$ and $\mathrm{MGC}_{1.5}$ were rejected on $8^{\text {th }}$ day.

\section{Microbiological analysis}

All the sample lots remained within the microbial acceptable limit of $7 \mathrm{log}$ cycle (ICMSF, 1998) during storage. However the variations in total plate count (TPC) was statistically significant during storage for all lots $(p<0.05)$. Between the sample lots, the variations in TPC were significant initially, whereas towards the final period of storage, $\mathrm{MGC}_{1.5}$ were significantly different $(\mathrm{p}<0.05)$ from other lots. These findings could be correlated with the antimicrobial property exhibited by green coffee extract and Bharath et al. (2015) have reported CGA, the active ingredient present in the unroasted green coffee beans, as responsible for its antimicrobial property.

The present study revealed the potentiality of green coffee extract as a natural additive by exploring it's in vitro antioxidant properties and antimicrobial activity as well as its suitability in chill stored mackerel mince for stabilisation. Incorporation of green coffee extract to such oxidation prone system gave protective effect from adverse changes like lipid and protein oxidation thus improving the quality. Further, most of these quality changes in nutrient components occurred simultaneously and hence could be assumed as correlated. Present study suggested a minimum concentration of $1 \%$ green coffee extract as effective in stabilising chill stored mackerel mince. However more detailed studies are required on characterisation of the extract and further possibilities of food applications.

\section{Acknowledgements}

The authors thank the Indian Council of Agricultural Research (ICAR), New Delhi for the financial support. Authors also thank all the technical and supporting staff of Mumbai Research Centre, ICAR-CIFT, for the support rendered during the study.

\section{References}

Abdel-Aal, H. A. 2001. Using antioxidants for extending the shelf life of frozen Nile karmout (Claries lazera) fish mince. J. Aquat. Food Prod. Technol., 10(4): 87-99.

Alov, P., Tsakovska, I. and Pajeva, I. 2015. Computational studies of free radical-scavenging properties of phenolic compounds. Curr. Top. Med. Chem., 15: 85-104.

Anbudhasan, P., Surendraraj, A., Karkuzhali, S. and Sathishkumaran, P. 2014. Natural antioxidants and its benefits. Int. J. Food Nutr. Sci., 3(6): 225-232.

AOAC 1989. Official methods of analysis, $14^{\text {th }}$ edn. Association of Official Analytical Chemists, Washington DC, USA

AOAC 2012. Official methods of analysis, $19^{\text {th }}$ edn. Association of Official Analytical Chemists, Washington DC, USA.

Badii, F. and Howell, N. K. 2002. Effect of antioxidants, citrate and cryoprotectants on protein denaturation and texture of frozen cod (Gadus morhua). J. Agric. Food Chem., 50: 2053-2061.

Baron, C. P., Kjaersgard, I. V. H., Jessen, F. and Jacobsen, C. 2007. Protein and lipid oxidation during frozen storage of rainbow trout (Oncorhynchus mykiss). J. Agric. Food Chem., 55: 8118-8125.

Benzie, I. F. F. and Strain, J. J. 1996. The ferric reducing ability of plasma (FRAP) as a measure of "antioxidant power": the FRAP assay. Anal. Biochem., 239: 70-76.

Bharath, N., Sowmya, N. K. and Mehta, D. S. 2015. Determination of antibacterial activity of green coffee bean extract on periodontogenic bacteria like Porphyromonas gingivalis, Prevotella intermedia, Fusobacterium nucleatum and Aggregatibacter actinomycetemcomitans: An in vitro study. Contemp. Clin. Dent., 6: 166-169.

Blois, M. S. 1958. Antioxidant determination by the use of stable free radicals. Nature, 181: 1199-2000.

Bubonja-Sonje, M., Giacometti, J. and Abram, M. 2011. Antioxidant and antilisterial activity of olive oil, cocoa and rosemary extract polyphenols. Food Chem., 127: 1821-1827.

Chaijana, M., Benjakula, S., Visessanguanb, W. and Faustman, C. 2005. Changes of pigments and color in sardine (Sardinella gibbosa) and mackerel (Rastrelliger kanagurta) muscle during iced storage. Food Chem., 93: 607-617. 
Cheng, Q. and Sun, D. W. 2008. Factors affecting the water holding capacity of red meat products: A review of recent research advances. Crit. Rev. Food Sci. Nutr., 48: 137-159.

CLSI 2012. Methods for dilution antimicrobial susceptibility tests for bacteria that grow aerobically: Approved standard. Clinical and Laboratory Standards Institute, CLSI publication M7-A9, Wayne, PA.

Connell, J. J. 1990. Methods of assessing and selecting for quality. In: Connell, J. J. (Ed.), Control of fish quality. $3^{\text {rd }}$ edn. Fishing News Books, Oxford, p. 122-150.

Działo, M., Mierziak, J., Korzun, U., Preisner, M., Szopa, J. and Kulma, A. 2016. The potential of plant phenolics in prevention and therapy of skin disorders. Int. J. Mol. Sci., 17: 160 pp. doi:10.3390/ijms17020160.

Elliot, J. G. 1999. Application of antioxidant vitamins in foods and beverages. Food Technol., 53: 46-48.

Ellman, G. L. 1959. Tissue sulfhydryl groups. Arch. Biochem. Biophys., 82: 70-77.

EUCAST 2003. European Committee on Antimicrobial Susceptibility Testing (EUCAST) of the European Society for Clinical Microbiology and Infectious Diseases (ESCMID). EUCAST Discussion Document E. Dis 5.1: Determination of minimum inhibitory concentrations (MICs) of antibacterial agents by broth dilution. Clin. Microbiol. Infect., 9: 1-7.

Fardiaz, S. 1995. Antimicrobial activity of coffee (Coffea robusta) extract. ASEAN Food J., 10: 103-106.

Farvin, K. H. S., Grejsen, H. D. and Jacobsen, C. 2012. Potato peel extract as a natural antioxidant in chilled storage of minced horse mackerel (Trachurus trachurus): Effect on lipid and protein oxidation. Food Chem., 131: 843-851.

Fecka, I., Raj, D. and Krauze-Baranowska, M. 2007. Quantitative determination of four water-soluble compounds in herbal drug from Lamiaceae using different chromatographic techniques. Chromatographia, 66: 87-93.

Fidrianny, I. and Annisa, Ruslan, K. 2016. Antioxidant activities of Arabica green coffee from three regions using ABTS and DPPH assays. Asian J. Pharm. Clin. Res., 9: 189-193.

Frankel, E. N. 2005. Lipid oxidation. $2^{\text {nd }}$ edn., The Oily Press, P. J. Barnes Associates, Bridgwater, UK.

Garces, G. A., Auguste, R. and Eric, B. 2016. Improving users' product acceptability: an approach based on Bayesian networks and a simulated annealing algorithm. Int. J. Prod. Res., 54, http://dx.doi.org/10.1080/00207543.2016.1156183.

Gram, L. and Dalgaard, P. 2002. Fish spoilage bacteria-problems and solutions. Curr. Opin. Biotechnol., 13: 262-266.

ICMSF 1998. Microorganisms in foods. International Commission on Microbiological Specification for Food. Microbial ecology of foods, Blackie Academic and Professional, London.
Lanier, T. C. 2000. Surimi gelation chemistry. In: Park, J. W. (Ed.), Surimi and surimi seafood, Marcel Dekker, New York, USA, p. 237-265.

Lee, K. W. and Lip, G. Y. H. 2003. The role of omega-3 fatty acids in the secondary prevention of cardiovascular disease. Q. J. Med., 96: 465-480.

Liaudanskas, M., Viskelis, P., Raudonis, R., Kviklys, D., Uselis, N. and Janulis, V. 2014. Phenolic composition and antioxidant activity of Malus domestica leaves. Sci. World J. doi: $10.1155 / 2014 / 306217$.

Lowry, O. H., Rosebrough, N. J., Farr, A. L. and Randall, R. J. 1951. Protein measurement with the Folin phenol reagent. J. Biol. Chem., 193(1): 265-275.

Medina, I., Gallardo, J. M., Gonzaalez, M. J., Lois, S. and Hedges, N. 2007. Effect of molecular structure of phenolic families as hydroxycinnamic acids and catechins on their antioxidant effectiveness in minced fish muscle. J. Agric. Food Chem., 55: 3889-3895.

Meilgaard, M., Civille, G. V. and Carr, B. T. 2006. Sensory evaluation techniques, $4^{\text {th }}$ edn. CRC Press, Boca Raton, USA, 464 pp.

Nisa, K. and Asadullah, K. 2011. Seasonal variation in chemical composition of the Indian mackerel (Rastrelliger kanagurta) from Karachi Coast. Iran. J. Fish. Sci., 10: 67-74.

Oyaiza, M. 1986. Studies on products of browning reaction: Antioxidative activity of products of browning reaction prepared from glucosamine. J. Nutr., 44: 307-315.

Parvathy, U. and George, S. 2014. Influence of cryoprotectant levels on storage stability of surimi from Nemipterus japonicus and quality of surimi-based products. J. Food Sci. Technol., 51: 982-987.

Pearson, A. M. and Dutson, T. R. 1994. Quality attributes and their measurement in meat, poultry and fish products. Blackie Academic and Professional, Glasgow, U. K.

Pyrzynska, K. and Pekal, A. 2013. Application of free radical diphenylpicrylhydrazyl (DPPH) to estimate antioxidant capacity of food samples. Anal. Methods, 5: 4288-4295.

Rawdkuen, S., Sai-Ut, S., Khamsorn, S., Chaijan, M. and Benjakul, S. 2009. Biochemical and gelling properties of tilapia surimi and protein recovered using an acid-alkaline process. Food Chem., 112: 112-119.

Sentkowska, A., Jeszka-Skowron, M. and Pyrzynska, K. 2016. Comparative studies on the antioxidant properties of different green coffee extracts. MOJ Food Proc. Technol., 3: 00071. DOI: 10.15406/mojfpt.2016.03.00071.

Shahidi, F. 2005. Bailey's industrial oil and fat products. John Wiley and Sons, New Jersey.

Shahidi, F. 2008. Nutraceuticals and functional foods: Whole versus processed foods. Trends Food Sci. Technol., 20: 376-387. 
Shahidi, F. and Chandrasekara, A. 2010. Hydroxycinnamates and their in vitro and in vivo antioxidant activities. Phytochem. Rev., 9: 147-170.

Shimada, K., Fujikawa, K., Yahara, K. and Nakamura, T. 1992. Antioxidative properties of xanthone on the auto oxidation of soybean in cylcodextrin emulsion. J. Agric. Food Chem., 40: 945-948.

Singleton, V. L. and Rossi, J. A. 1965. Colorimetry of total phenolics with phosphomolybdic-phosphotungstic acid reagents. Am. J. Enology Vitic, 16: 144-158.

Siva, R., Rajikin, N., Haiyee, Z. A. and Ismail, W. I. W. 2016. Assessment of antioxidant activity and total phenolic content from green coffee robusta sp. beans. Malay. J. Anal. Sci., 20: 1059-1065.

Suvanich, V., Jahncke, M. L. and Marshall, D. L. 2000. Changes in selected chemical quality characteristics of channel catfish frame mince during chill and frozen storage. J. Food Sci., 65: 24-29.

Suzuki, T. 1981. Fish and krill protein processing technology. Applied Science Publishers Ltd., London, 260 pp.

Tarladgis, G. B., Watts, M. B. and Younathan, T. M. 1960. A distillation method for the quantitative determination of malonaldehyde in rancid foods. J. Am. Oil Chem. Soc., 37: $44-50$.

USFDA 2001. Aerobic plate count. Bacteriological analytical manual, United States Foods and Drugs Administration. USA.

Viji, P., Binsi, P. K., Visnuvinayagam, S., Bindu, J., Ravishankar, C. N. and Gopal, T. K. S. 2015. Efficacy of mint (Mentha arvensis) leaf and citrus (Citrus aurantium) peel extracts as natural preservatives for shelf life extension of chill stored Indian mackerel. J. Food Sci. Technol., 52(10): 6278-6289. 